\title{
Novel Ergopeptides as Dual Ligands for Adenosine and
}

\section{Dopamine Receptors}

\author{
Marc Vendrell, Ester Angulo, Vicent Casadó, Carme Lluis, Rafael Franco, Fernando Albericio and \\ Miriam Royo
}

\section{Supporting Information}

\section{Table of Contents}

Tables with chemical structures, HPLC data and yields for the whole library of ergopeptides and $\mathrm{N}^{\alpha}-$ acetylated tripeptides.

Table with HPLC data of resynthesized ergopeptides.

Figures containing results for radioligand binding competition experiments for the whole library and $\mathrm{N}^{\alpha}$-acetylated tripeptides. 
Table 1. Chemical structures, HPLC data and yields for the whole library of ergopeptides.

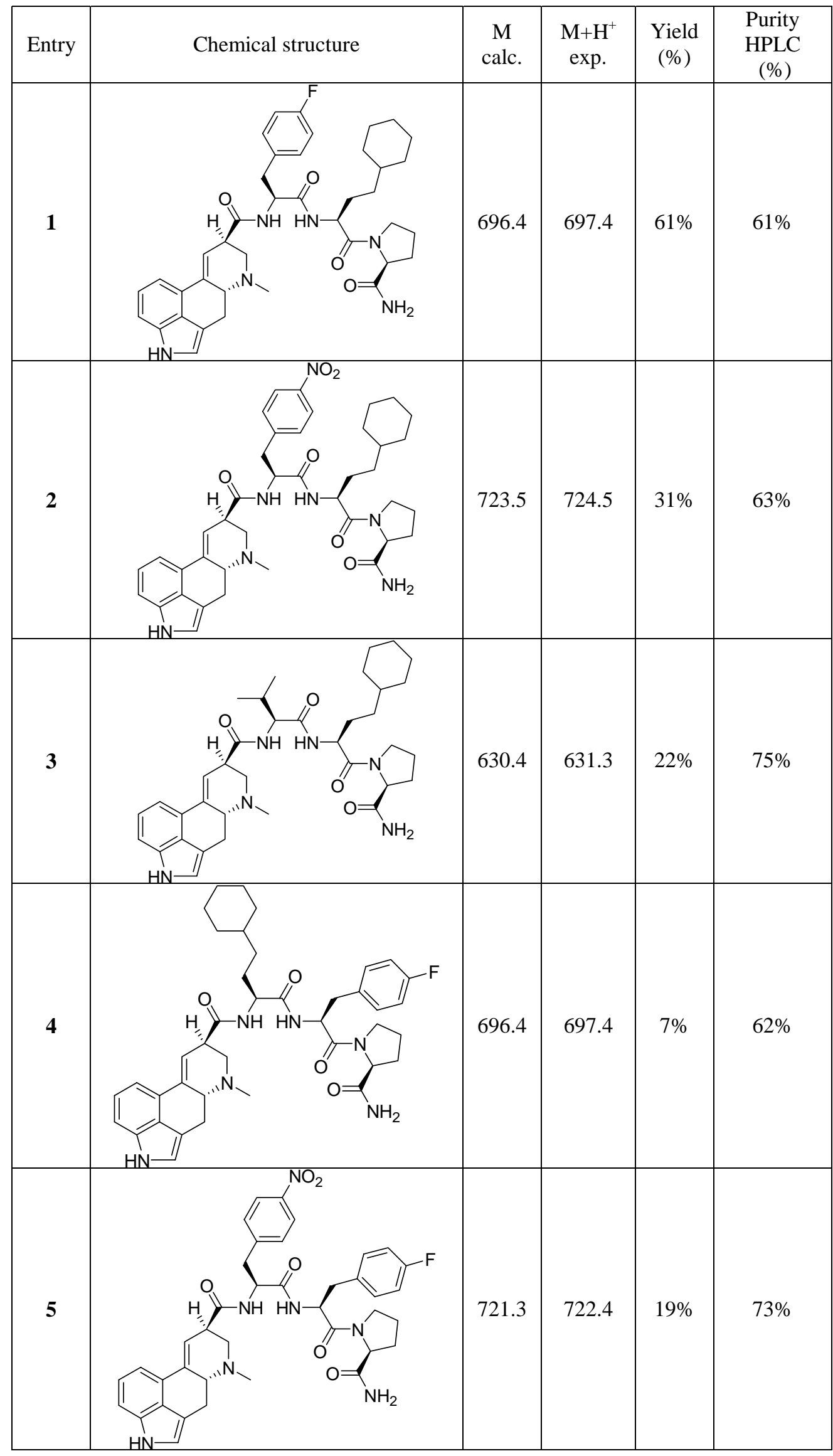




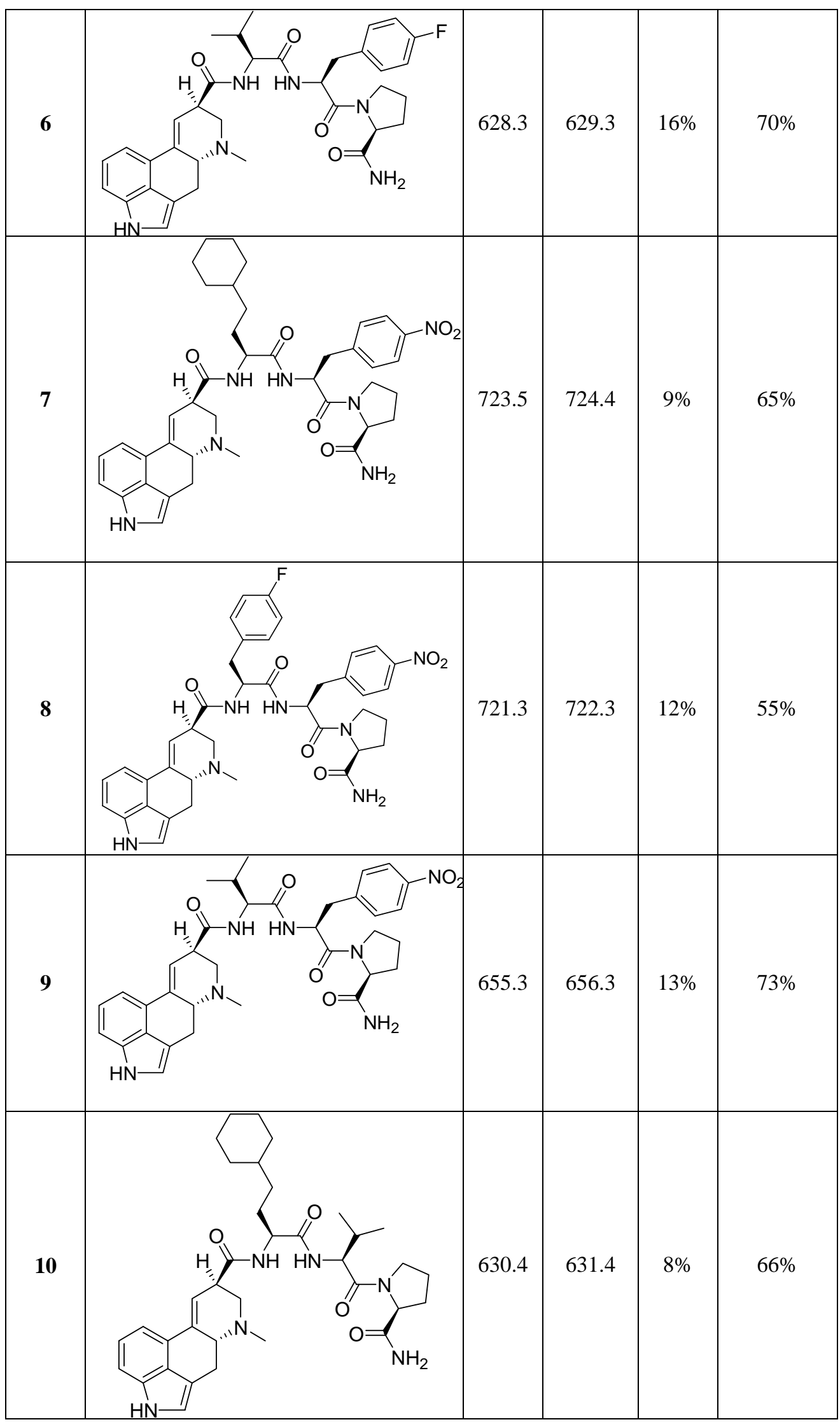




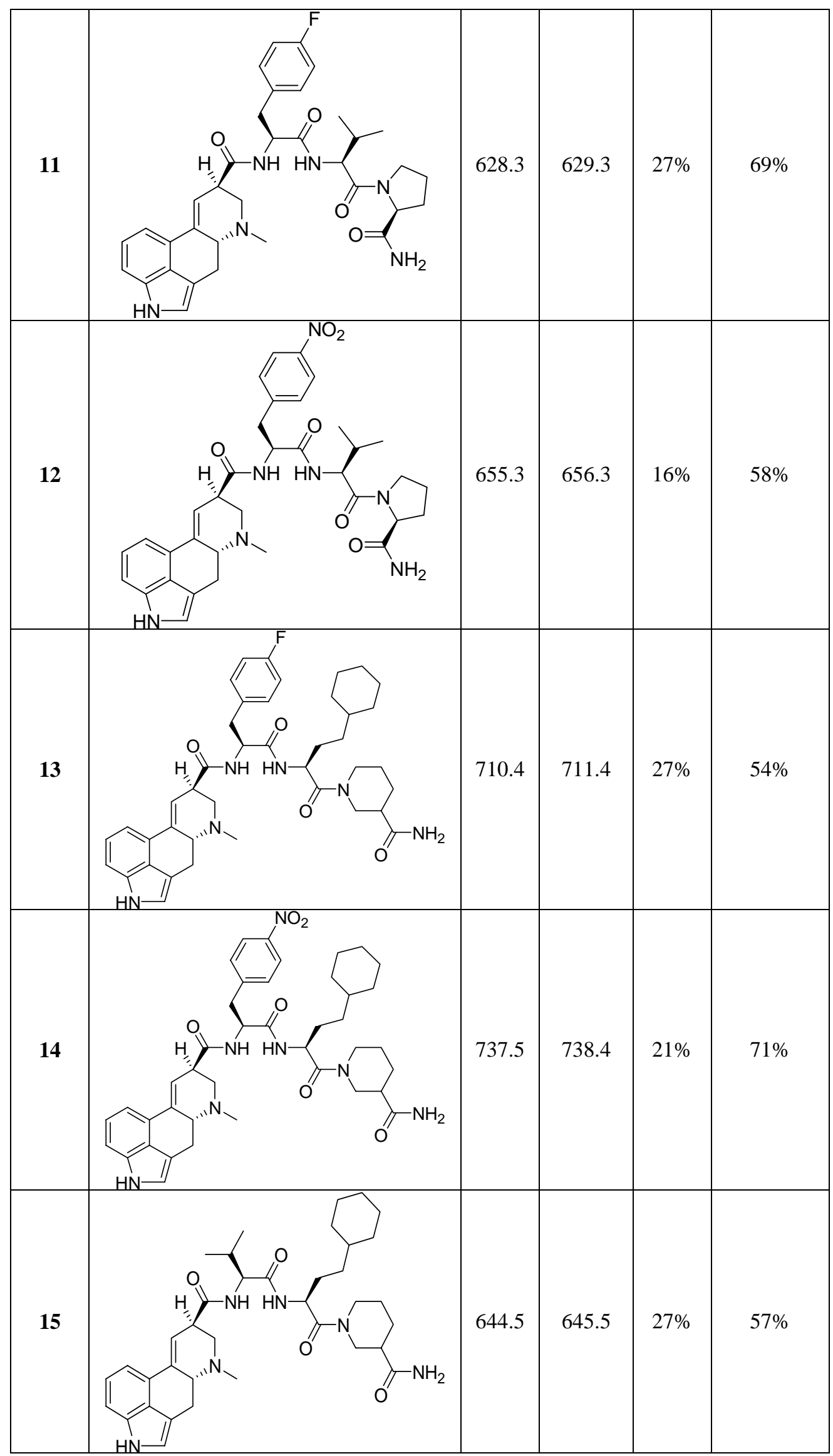




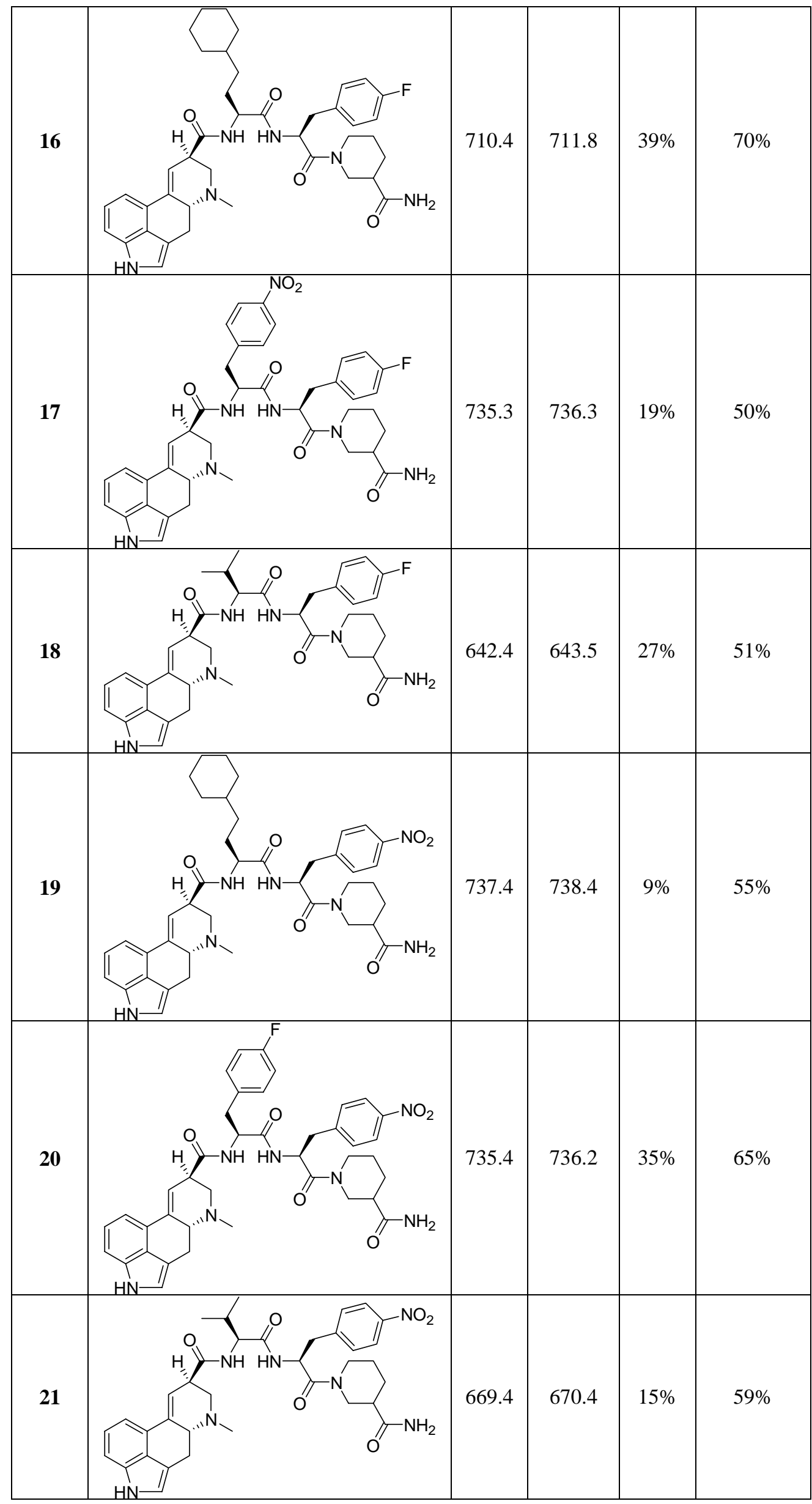




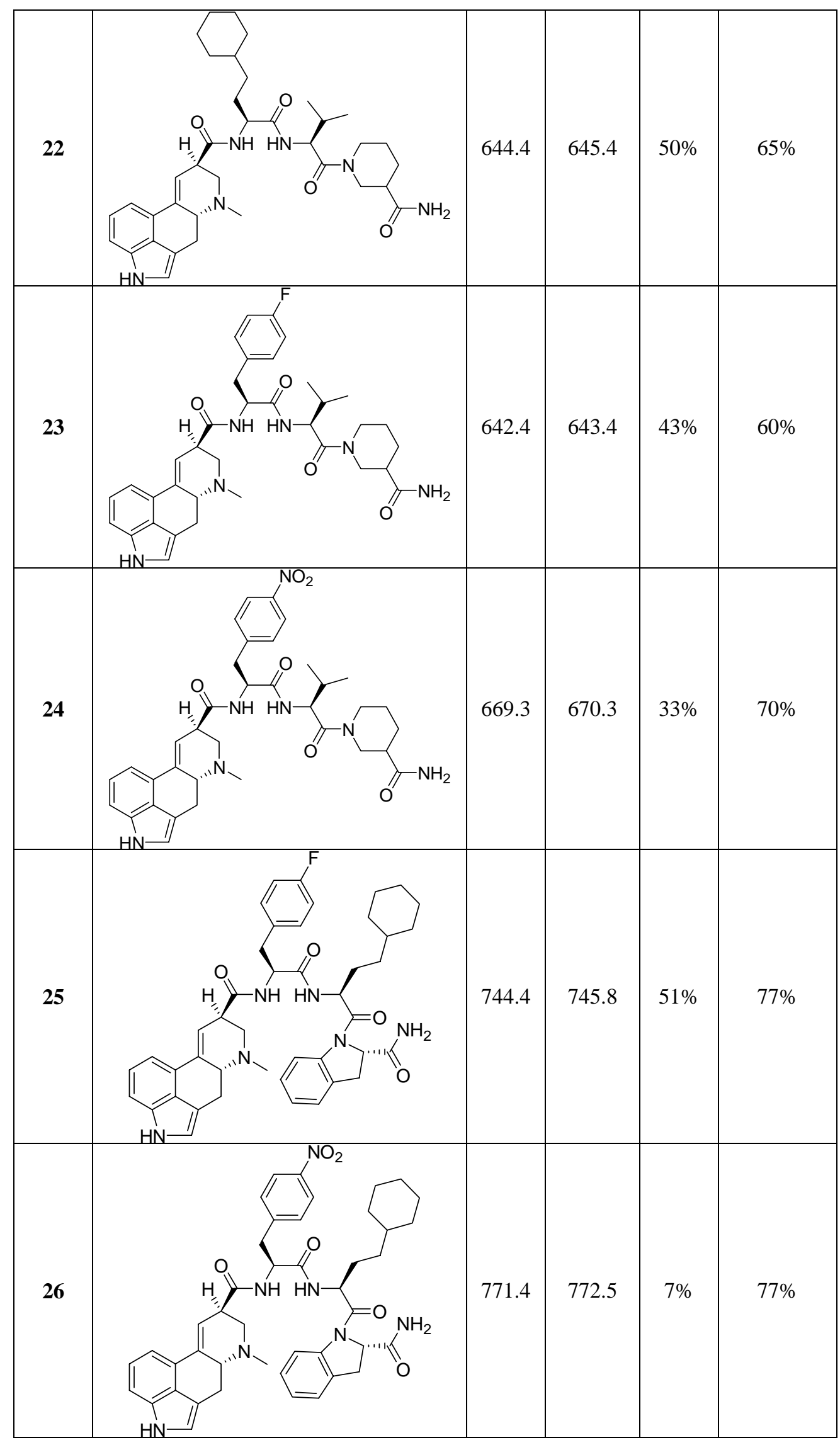




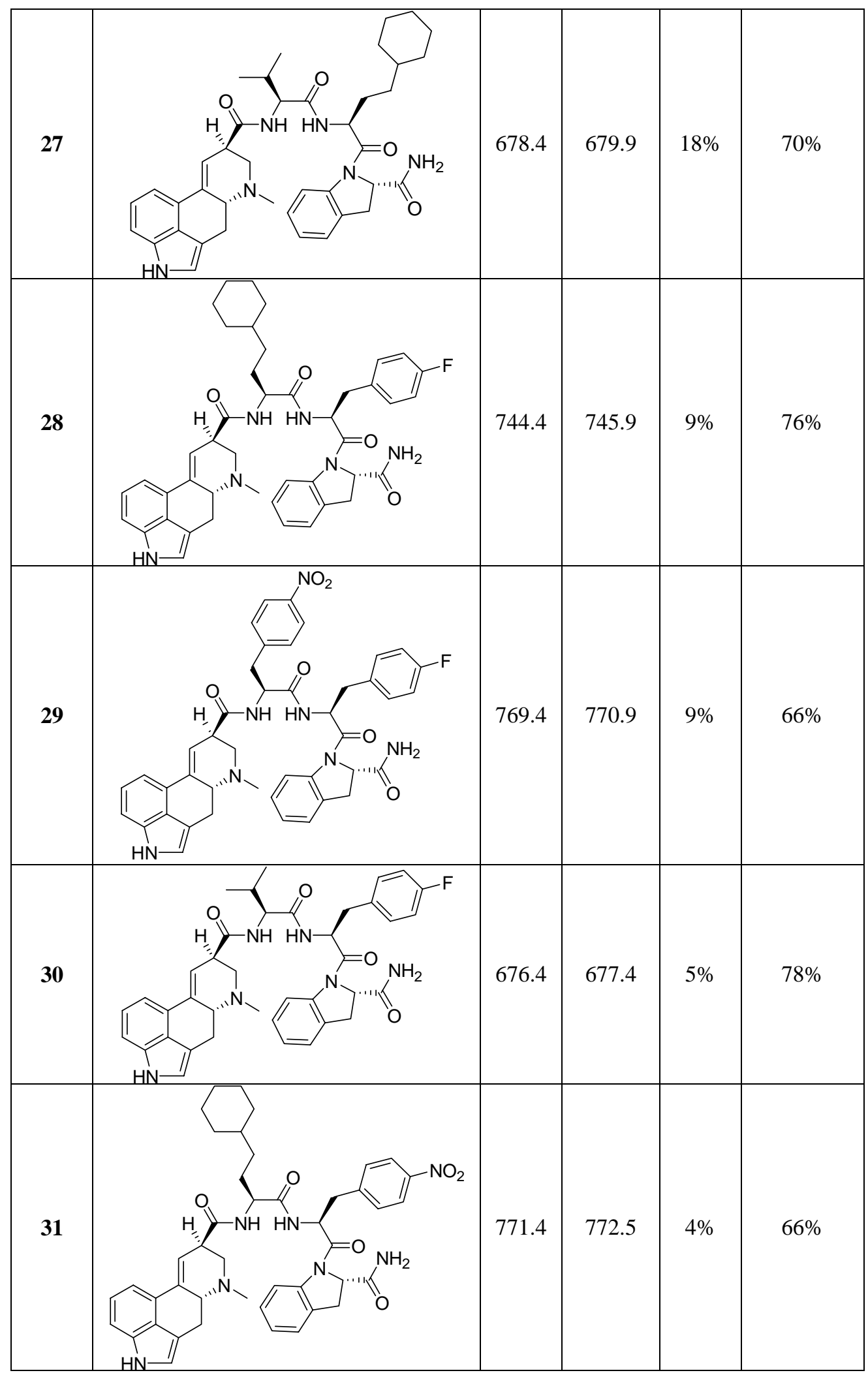




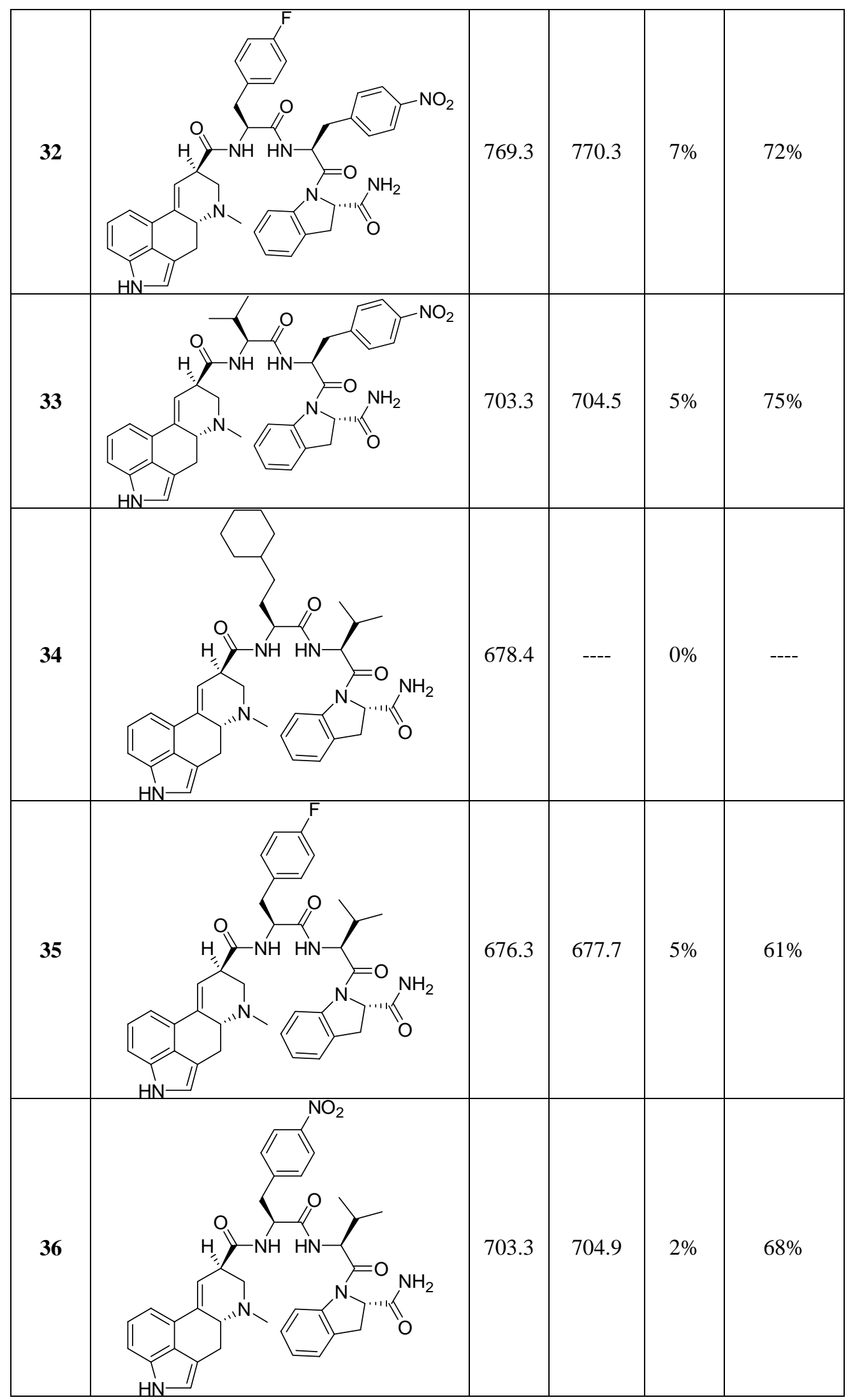




\begin{tabular}{|l|l|l|l|l|}
\hline 37 & 267.1 & 268.1 & $32 \%$ & $62 \%$ \\
\hline
\end{tabular}

HPLC conditions: A: $\mathrm{H}_{2} \mathrm{O}-\mathrm{TFA}$ : 99.9:0.1, B: ACN-TFA: 99.9:0.1; gradient 0\% B to 100\% B in 15 min. Compounds were detected by UV absorption at $220 \mathrm{~nm}$. 

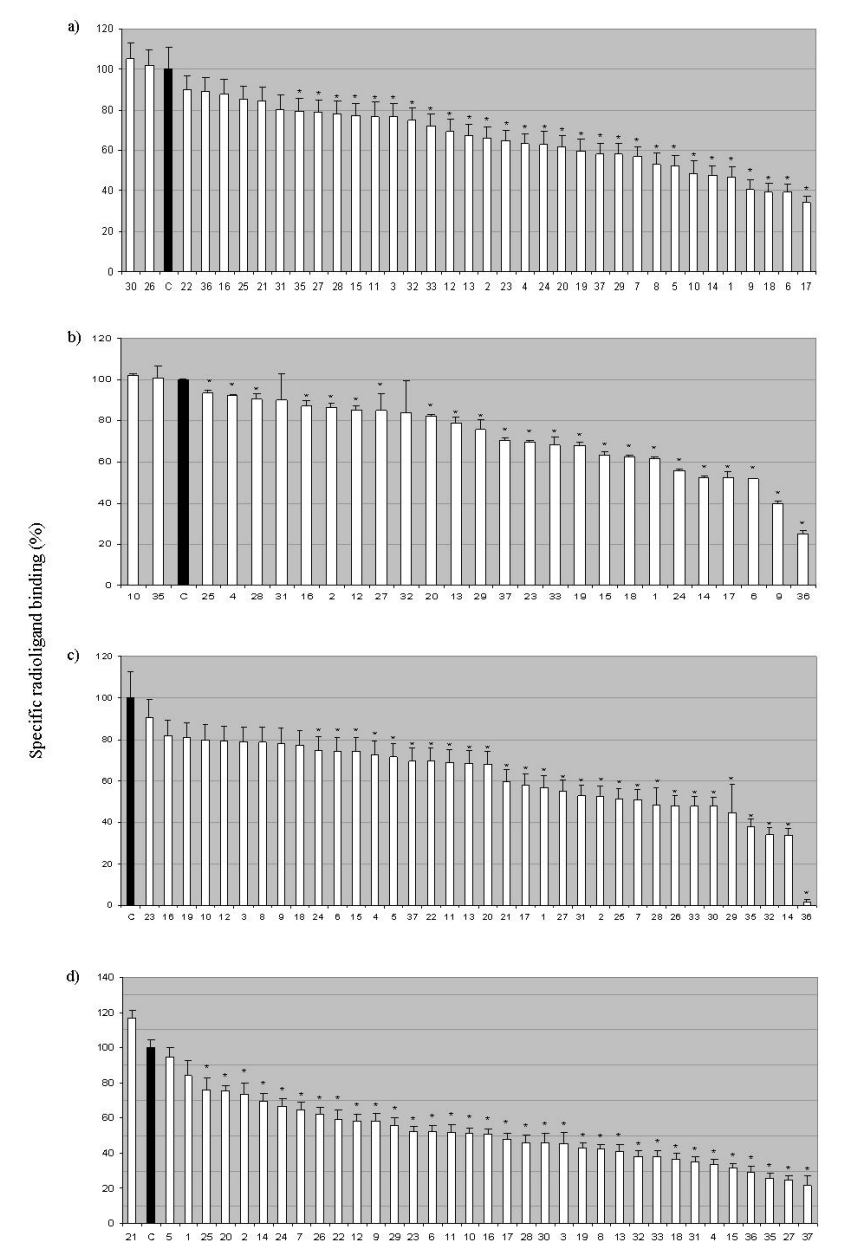

Figure 1. Specific binding as percentage of radioligand binding in the absence of competing ligand was measured as indicated in the Experimental Section. C (black): control of radioligand binding without competing ligand; 1-36: radioligand specific binding in the presence of $50 \mu \mathrm{M}$ of the corresponding ergopeptides; 37: radioligand specific binding in the presence of $50 \mu \mathrm{M}$ of D-lysergilamide. Radioligands used: a) $1.2 \mathrm{nM} \mathrm{D} \mathrm{D}_{1} \mathrm{R}$ antagonist $\left[{ }^{3} \mathrm{H}\right]-\mathrm{SCH}$; b) $0.9 \mathrm{nM} \mathrm{D} 2 \mathrm{R}$ antagonist $\left[{ }^{3} \mathrm{H}\right]-\mathrm{YM}$; c) $2.2 \mathrm{nM}$

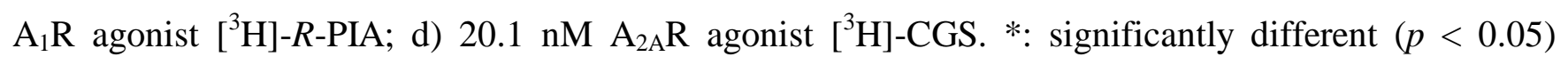
compared to control. 

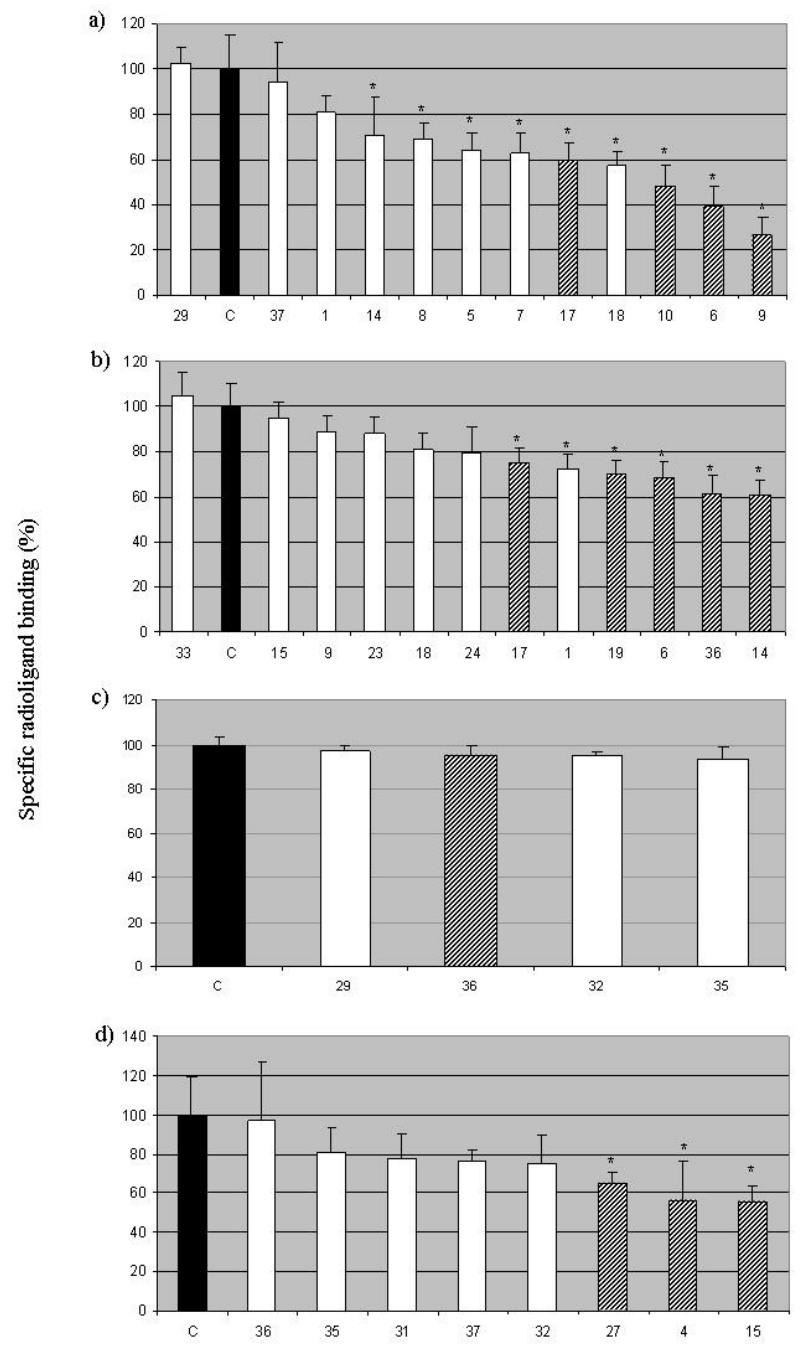

Figure 2. Competition experiments for ergopeptides with the capacity to displace more than $50 \%$ of the specific radioligand binding. Specific binding as percentage of radioligand binding in the absence of competing ligand was measured as indicated in the Experimental Section. C (black): control of radioligand binding without competing ligand; 1-37: radioligand specific binding in the presence of ergopeptides (1-36) or D-lysergilamide (37) at a concentration of $500 \mathrm{nM}$ for $\mathrm{D}_{1} R, 5 \mu \mathrm{M}$ for $\mathrm{D}_{2} \mathrm{R}, 10 \mathrm{nM}$ for $\mathrm{A}_{1} \mathrm{R}$ and $100 \mathrm{nM}$ for $\mathrm{A}_{2 \mathrm{~A}} \mathrm{R}$. Radioligands used: a) $2.0 \mathrm{nM} \mathrm{D} \mathrm{D}_{1}$ antagonist $\left[{ }^{3} \mathrm{H}\right]-\mathrm{SCH}$; b) $0.9 \mathrm{nM} \mathrm{D}{ }_{2} \mathrm{R}$ antagonist [ $\left.{ }^{3} \mathrm{H}\right]-\mathrm{YM}$; c) $3.6 \mathrm{nM} \mathrm{A}_{1} \mathrm{R}$ agonist $\left[{ }^{3} \mathrm{H}\right]-R$-PIA; d) $19.1 \mathrm{nM} \mathrm{A} \mathrm{A}_{2 \mathrm{~A}} \mathrm{R}$ agonist [ $\left.{ }^{3} \mathrm{H}\right]-\mathrm{CGS}$. Compounds in grey striped bars were selected for further experiments. *: significantly different $(p<$ 0.05) compared to control. 
Table 2. Chemical structures, HPLC data and yields for $\mathrm{N}^{\alpha}$-acetylated tripeptides.

\begin{tabular}{|c|c|c|c|c|c|c|}
\hline Entry & Chemical structure & $\begin{array}{c}\mathrm{M} \\
\text { calc. }\end{array}$ & $\begin{array}{l}\mathrm{M}+\mathrm{H}^{+} \\
\text {exp. }\end{array}$ & $\begin{array}{c}\text { Yield } \\
(\%)\end{array}$ & $\begin{array}{c}\text { Purity (\%) } \\
\text { HPLC } \\
\text { system } 1\end{array}$ & $\begin{array}{c}\text { Purity }(\%) \\
\text { HPLC } \\
\text { system } 2\end{array}$ \\
\hline 38 & & 488.3 & 489.2 & $34 \%$ & $86 \%$ & $82 \%$ \\
\hline 39 & & 420.2 & 421.3 & $38 \%$ & $81 \%$ & $80 \%$ \\
\hline 40 & & 447.2 & 448.2 & $55 \%$ & $97 \%$ & $96 \%$ \\
\hline 41 & & 422.3 & 423.2 & $40 \%$ & $87 \%$ & $87 \%$ \\
\hline 42 & & 529.2 & 530.2 & $36 \%$ & $82 \%$ & $80 \%$ \\
\hline 43 & & 436.3 & 437.3 & $55 \%$ & $91 \%$ & $91 \%$ \\
\hline 44 & & 527.2 & 528.2 & $49 \%$ & $72 \%$ & $70 \%$ \\
\hline
\end{tabular}




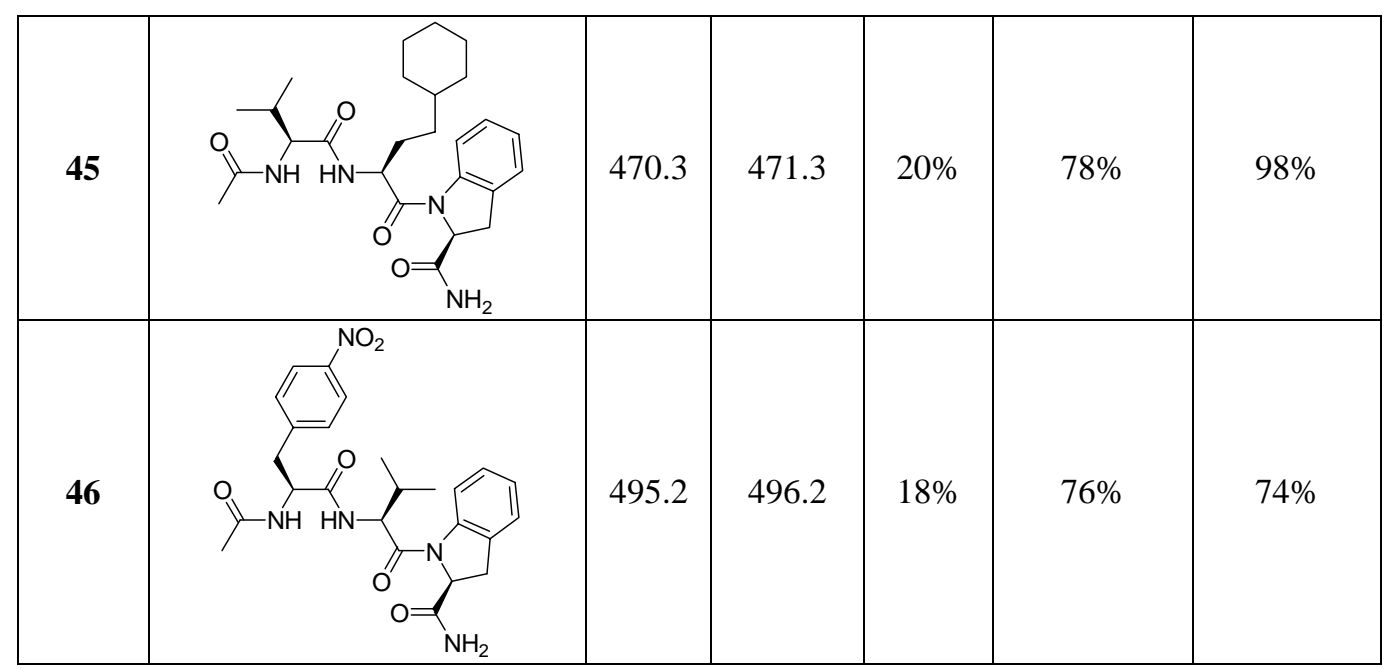

HPLC system 1: A: $\mathrm{H}_{2} \mathrm{O}-\mathrm{TFA}: 99.9: 0.1$, B: ACN-TFA: 99.9:0.1; gradient 0\% B to 70\% B in 15 min. HPLC system 2: A: $\mathrm{H}_{2} \mathrm{O}-\mathrm{HCOOH}$ : 99.9:0.1, B: ACN-HCOOH: 99.93:0.07; gradient 0\% B to 70\% $\mathrm{B}$ in $15 \mathrm{~min}$. Compounds were detected by UV absorption at $220 \mathrm{~nm}$. 

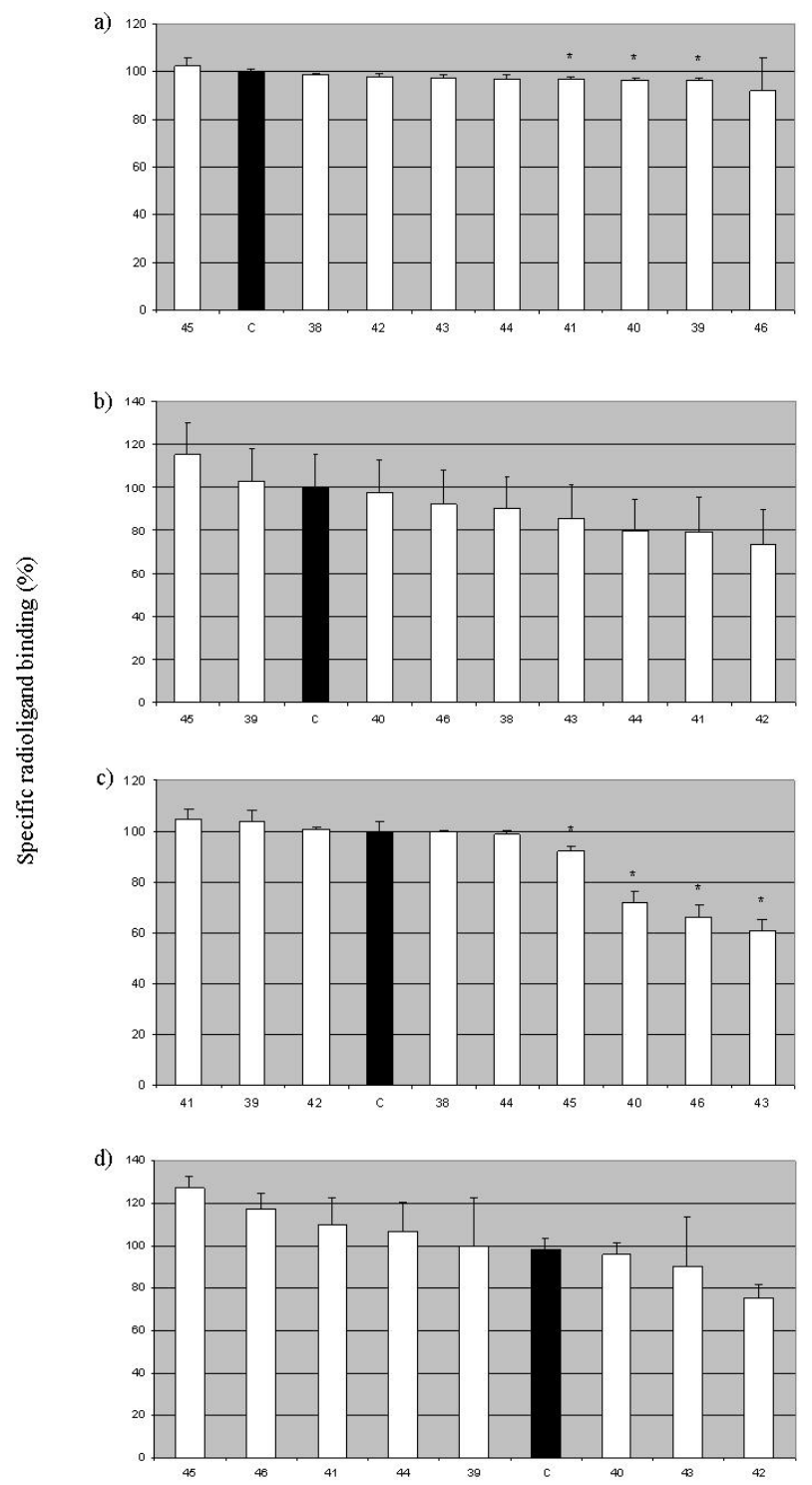

Figure 3. Competition radioligand binding experiments for $\mathrm{N}^{\alpha}$-acetylated tripeptides. Specific binding as percentage of radioligand binding in the absence of competing ligand was measured as indicated in the Experimental Section. C (black): control of radioligand binding without competing ligand; 38-46: radioligand specific binding in the presence of $50 \mu \mathrm{M}$ tripeptides. Radioligands used: a) $1.1 \mathrm{nM} \mathrm{D}_{1} \mathrm{R}$ antagonist $\left[{ }^{3} \mathrm{H}\right]-\mathrm{SCH}$; b) $0.7 \mathrm{nM} \mathrm{D} \mathrm{D}_{2} \mathrm{R}$ antagonist $\left[{ }^{3} \mathrm{H}\right]-\mathrm{YM}$; c) $0.9 \mathrm{nM} \mathrm{A}$ R agonist [ $\left.{ }^{3} \mathrm{H}\right]-R$-PIA; d) 1.4 nM $A_{2 A} \mathrm{R}$ agonist $\left[{ }^{3} \mathrm{H}\right]-\mathrm{ZM}$. *: significantly different $(p<0.05)$ compared to control. 
Table 3. HPLC data of resynthesized ergopeptides.

\begin{tabular}{|c|c|c|c|}
\hline Entry & Chemical structure & $\begin{array}{c}\text { Purity (\%) } \\
\text { HPLC } \\
\text { system } 1\end{array}$ & $\begin{array}{c}\text { Purity (\%) } \\
\text { HPLC } \\
\text { system } 2\end{array}$ \\
\hline 4 & & $93 \%$ & $93 \%$ \\
\hline 6 & & $97 \%$ & $91 \%$ \\
\hline $9 a$ & & $98 \%$ & $98 \%$ \\
\hline $9 b$ & & $99 \%$ & $99 \%$ \\
\hline 10 & & $99 \%$ & $98 \%$ \\
\hline 14 & & $85 \%$ & $91 \%$ \\
\hline 15 & & $99 \%$ & $95 \%$ \\
\hline
\end{tabular}




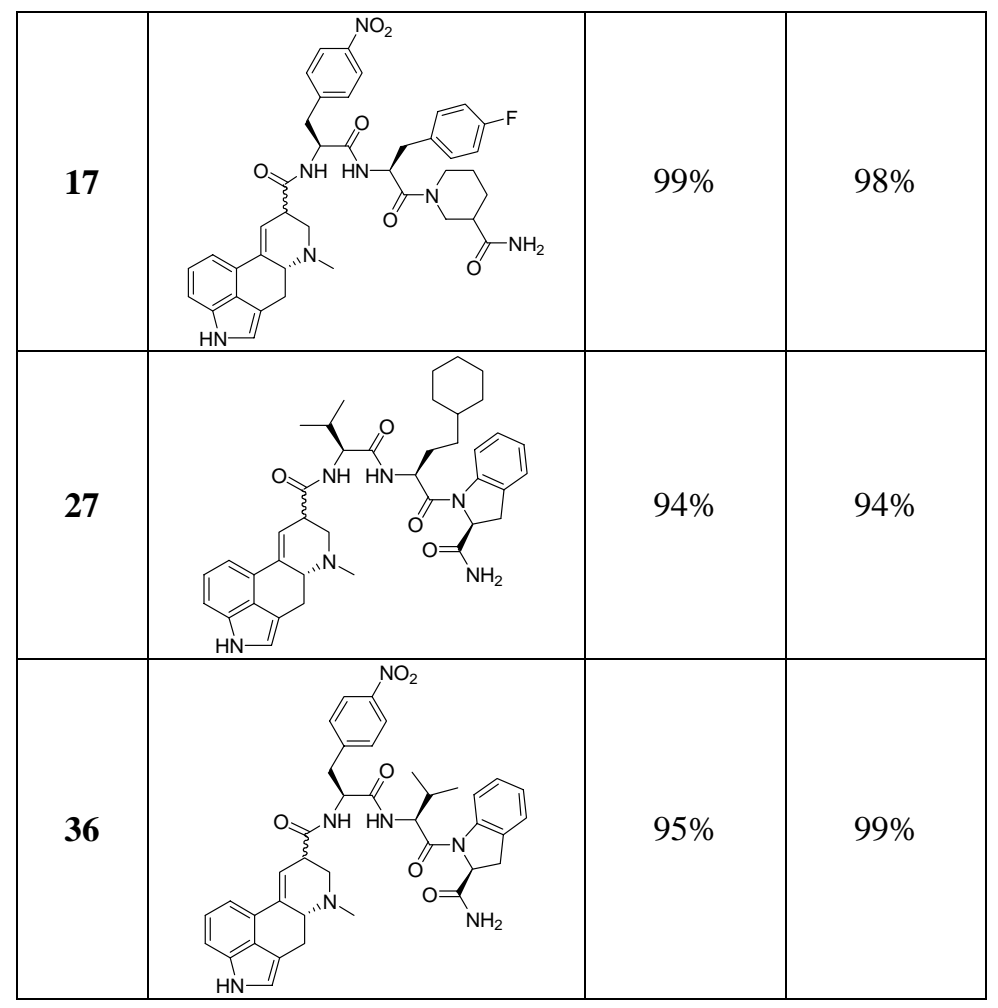

HPLC system 1: A: $\mathrm{H}_{2} \mathrm{O}-\mathrm{TFA}: 99.9: 0.1, \mathrm{~B}$ : ACN-TFA: 99.9:0.1; gradient 0\% B to 100\% B in 20 min. HPLC system 2: A: $\mathrm{H}_{2} \mathrm{O}-\mathrm{HCOOH}$ : 99.9:0.1, B: ACN-HCOOH: 99.3:0.07; gradient 0\% B to 100\% B in 20 min. Compounds were detected by UV absorption at $220 \mathrm{~nm}$. 